\title{
FINANCIAL TRANSACTION MONITORING SOFTWARE TOOL IN THE UNIVERSITY BUSINESS ENVIRONMENT
}

\author{
Milovan Stanišić, \\ Miloš Dobrojević*, \\ Marko Milojević
}

Singidunum University, Belgrade, Serbia
Correspondence:

Miloš Dobrojević

e-mail:

mdobrojevic@singidunum.ac.rs

\begin{abstract}
:
Financial flows within a single company can be very complex and difficult to track, even when the business operations are monitored by use of advanced information systems. A large number of transactions, on one hand, and a large turnover of goods and / or services on the other, besides making difficult to perceive the current situation in full, creates a favorable environment for the emergence of financial crime. This paper describes a software tool developed in the form of web application that monitors data from multiple external sources (information systems) paraphrase, and then displays the obtained results graphically or in spreadsheet format. The purpose of this software is to make it easier for middle and top management to perceive the current balance of the company, controlling of vital financial information, budgeting and planning of capital expenditures, thus facillitating foreseeing and making of short and long-term business decisions. Although initially intendend for use in the university business environment, this software application possesses the potential to be used in other industries as well.
\end{abstract}

\section{Keywords:}

financial flows tracking, financial information system, asynchronous web applications, web technologies, university financial management.

\section{INTRODUCTION}

Financial flows within a single company can be very complex and difficult to track, even when the business operations are monitored by use of advanced information systems. A large number of transactions, use of multiple independent information systems, data redundancy, unstandardized document formats used for data transfer and exchange and human factor involved in information processing create favourable environment for both unintentional errors and harmful actions such as attempt to conceal or fabricate information.

Continued monitoring of current business operations with tens of thousands of transactions on a daily basis represents a true challenge for every modern-day corporation. Proper identification of transactions and its classification, verification and record-keeping, with minimum room for errors, is what contemporary managements seeks to achieve, according to Horngren \& Harrison (2012). Elimination of the human factor in transaction processing and ability of the application to recognize, detect and, in the future, learn how to keep records of a specific transaction will be a comparative advantage of one company over the other. Only companies whose management has adopted the vision which recognizes these values stand a chance to survive. Human factor will inevitably remain involved in the record-keeping of transactions. However, in practice, the number of alternatives and options for occurrence of intentional or accidental errors needs to be minimised. The main hypothesis of this paper is to provide substantiated evidence for the existence of the need to have an algorithm i.e. tool in place which would ensure that payments are properly matched to clients' accounts i.e. accurate processing of transactions based on the purpose of the payment made. 
This includes the use of machine learning, professional accounts receivable management and insight into company's (institution's) selling mix.

This paper describes the software tool developed in the form of a web application which monitors data from multiple external sources (information systems) in real-time, cross-references, processes and filters it, and then displays the obtained results. Software was originally developed by prof. Milovan Stanišić, $\mathrm{PhD}$ and docent Miloš Dobrojević, $\mathrm{PhD}$ on Magma Nano ${ }^{\text {tm }}$ platform (framework).

The purpose of this software is to make it easier for middle and top management to perceive the current balance of the company, to control vital financial information, budgeting and planning of capital expenditures, and make short and long-term business decisions.

Provision of such information will enable the management to act more quickly, accurately and adequately in the decision-making process. It will be particularly beneficial for reaching decisions related to liquidity and financial management.

\section{LITERATURE REVIEW}

There are numerous papers published on the subject of importance of finances and the need for adequate and timely business monitoring. The use of monetary funds and adequate management of accounts receivable paint a clear picture of the management's competence (Barjaktarović et al, 2015). It is deemed that the characteristics and purpose of professional management is reflected in efficient use of these resources. Putting such resources to use and speeding up the flow of turnover pave the road for achieving the same turnover by utilising less funds i.e. generating higher income with the same amount of funds (Ivanis \& Nesić, 2011). Unengaged funds generated by adequate management can be used to improve services, enhance quality or create a reserve fund. Improved liquidity and resulting financial stability will ensure more comfortable position of the company's management and enable it to focus on new investment projects. Jeremić et al (2015) wrote about the importance of accounts receivable management. Accounts receivable management is a special technique and skill and largely affects company's performance. According to Barjaktarović et al (2015), accounts receivable management is dependent on the company's dominant activity. However, what is common to all of them is the fact that no company can be successful without maintaining adequate records on accounts receivable, without keeping business records in a timely fashion and without adequate customer policy in place. Modern corporations aim to integrate information about accounts receivable management with company resources. For this reason, in addition to software monitoring of accounts receivables, it is also important to be familiar with customer's habits and characteristics. The use of ERP solutions enabled these activities to get connected.

Some of the most renowned authors on this subject, Hall (2011), Lutovac \& Manojlov (2012), noted that the use of ERP solutions unambiguously increases efficiency and reduces the number of redundant jobs within an organisation. Adequate matching of the amount paid with the payee's account was the focal point during the design of the initial ERP solutions. This was the challenge faced by the architects of the information systems. The designed ready solutions already exist and are used in practice. However, globalism and market competitiveness the market has been on the rise, directing the companies towards broadening of their assortment of products and services on a daily basis (Milojević et al, 2016). According to Lečić \& Kupusinac (2013), there is not one successful compa-ny whose management is not looking at the company's challenges and opportunities with the view to expanding the assortment of its products and service. Thus, it also searches for errors which can be made when matching the amount paid with the customer's account. The situation becomes even more complex in cases when buyers have multiple options to choose from when making payments (mobile and office banking, at the bank) while the compa-ny (institution) captures data from multiple sources and in different formats. Additional difficulty may arise when the company's (institution's) information system is not in-tegrated. Communication between information systems, which receive data in different formats, along with an ever increasing assortment of products and services, may result in the fact that data processed within such a system lack absolute integrity and accuracy. In addition to this issue, a certain number of authors also point out the situation when a person with excessive authorisations within the system may choose, for the benefit of his/her own per-sonal interests, to present the data as different from what they actually are Mitra (1996), Njeguš (2009). This kind of situation can have far-reaching consequences both on company's performance and financial statements and on other employees by creating a false image of individual's performance. For this reason, we believe that every mod-ern company should possess a tool which will enable it to keep proper records of transactions originating from dif-ferent information systems. Many authors recommend to companies which possess a ready ERP solutionto develop their own tools as well in order to check whether the ERP solution functions adequately and to strengthen the inter-nal control systems (Marjanović, 2014). 


\section{UNIVERSITY'S ORGANISATIONAL STRUCTURE}

Pursuant to the Law on Higher Education of the Republic of Serbia, higher education activity may be performed, among others, by universities and faculties, where the university is a higher education institution (Article 44) and the faculties are considered higher education units comprising a university (Articles 45 and 57) which may but need not be legal entities.

The university shall integrate the functions of all the institutions and units that it comprises, particularly the faculties, by conducting a unified policy aimed at continual promotion of the quality of courses and improvement of scientific research, i.e. artistic work, innovation activity and provision of support to students in academic and career development.

To achieve these goals, the university shall have a special competence in the area of strategic planning, issuance of diplomas and diploma supplements, investment planning as well as creation and development of a unique information system (Article 58).
Separate units may exist as part of the University such as: Integrated University and faculties enjoying the status of a legal entity (Statute of the University of Singidunum, Article 18). As part of the Integrated University, there are different units: faculties, departments for postgraduate studies, higher education units located outside of the University's seat and which operate without the status of a legal entity, institutes and other organisational units (Article 19). Faculties operating within the Integrated University are higher education institutions without the status of a legal entity (Article 20). Model example of University's organizational structure is shown on Fig. 1.

Fig. 1: Model of University Structure

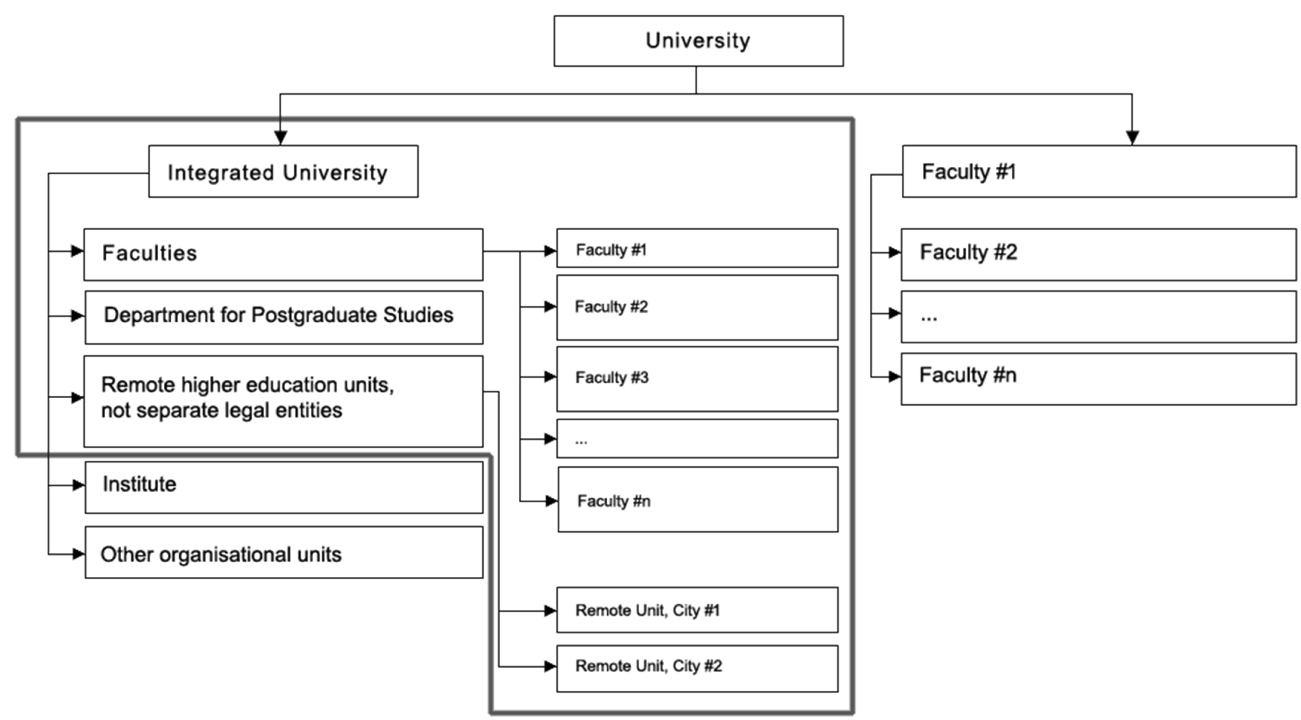

\section{PROVISION OF SERVICES}

If we take a very simplified view of the University as a business entity with a commercial purpose, Integrated University and its faculties offer a precisely defined set of services, where every service is provided at a set price. On the other hand, students are University's clients who receive a service or a set of services for the money they pay, provided that they have previously met all the requirements prescribed by the Law and the University's Statute.

University holds several special-purpose bank accounts in one or multiple banks to which students can make payments in order to settle their tuition fees, examination fees, to pay for enrolment material, insurance, etc. Depending on its purpose, a single bank account may be used by one or more faculties.

\section{Client identification}

All transactions are completed via payments made to one of the University's bank accounts. When making a payment, the student specifies the service he/she purchases (payment purpose) and provides his/her identification data by specifying his/her: 
- first name, last name and address (payer),

- number of his/her student's record-book or a unique personal identification number (reference no. / payment purpose).

\section{Information systems and centralised data warehousing}

In order to monitor its business activities, Serbian universities use commercial information systems designed specifically for higher education institutions (Faculty of Eletrical Engineering, University of Belgrade):

- FIS (Faculty Information System) which comprises a student administration office app, web portal for students and web portal for employees.

- FIMES, software for personnel record-keeping, financial operations, book-keeping and document archiving purpose.

In the course of the day, banks provide reports to universities on received payments via email and, among other things, in XML format. Employees in the university's accounting department then take records of such payments into the university's information system.

\section{HUMAN FACTOR ISSUES}

In the process of carrying out a transaction, the following points can be identified as places where human error can occur.

\section{Incoming payment}

The error can be the result of the failure on the part of the student to provide accurate and complete data or, in cases when the payment is made over the cash desk (bank or postal service), during manual entry of data by the teller. Some of the most common errors include:
- Incorrect reference number. Missing or mistyped number of the student's record-book or a unique identification number.

- Incorrect payer data. Results from a mistaken entry of transaction data, use of different alphabets (Cyrillic or Latin alphabet), improper use of graphs.

- Incorrect bank account number. Payment was made to the current bank account held by the Integrated University, but the bank account is used for another purpose.

- Incorrect amount. Student uses one payment order to make multiple payments specifying the sum of all individual payments. However, the transaction is not accompanied with data relevant for all services covered by the transaction.

-Incorrect payment purpose. In cases when the amount refers to multiple services and the "payment purpose" specifies only one of them or when it contains only a generic description of the purpose. For example, the case when "enrolment" is specified as the payment purpose, while it actually includes multiple services: variable part of the tuition fee, insurance and enrolment material.

\section{Data entry into information system}

At this stage, the employee of the university's accounting department is expected to enter data contained in the reports issued by the bank via email usually by using MS Word, MS Excel or PDF format into the university's information system which is a task that demands great focus and concentration. If there is an error made at the time of payment or a transaction covers multiple services, this task poses an additional workload for employees working on it, resulting in faster occurrence of fatigue and drop in concentration and thus a higher risk from human error.

FIG. 2: Architecture of the application, simplified diagram

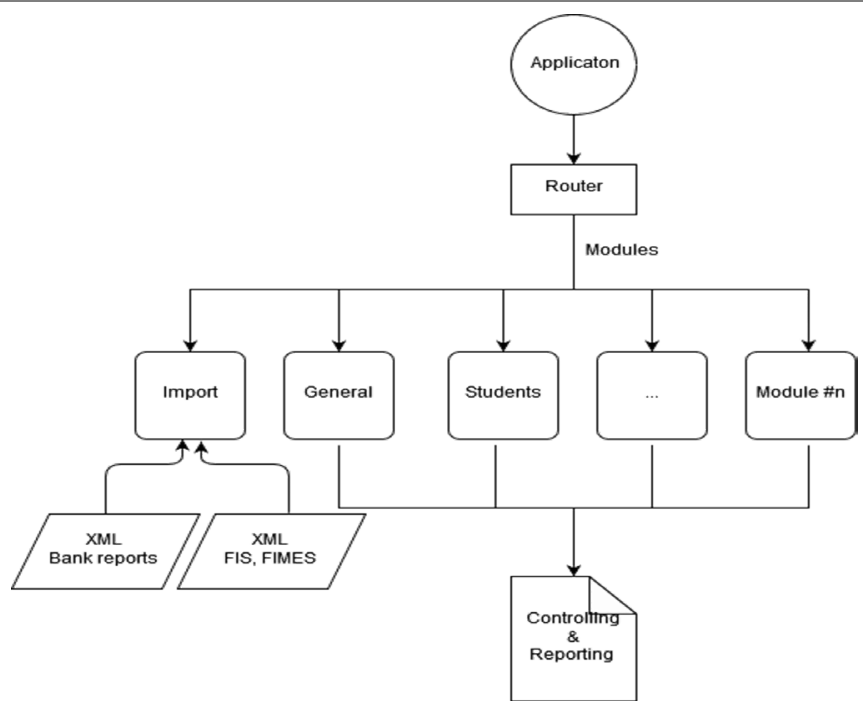




\section{TRANSACTION AND SERVICE MONITORING SOFTWARE SOLUTION}

\section{Software platform}

In an attempt to mitigate the effects which human factor may have on the accuracy of the financial reporting, an asynchronous web application based on the Magma $\mathrm{Nano}^{\mathrm{Tm}}$ Framework which supports $\mathrm{MVC}^{1}$ architecture (magma.rs, 2017) was developed. To ensure the proper functioning of this application, it is necessary to create a platform with an Apache2 web server, MySQL or Mari$\mathrm{aDB}$ database server and PHP program language.

\section{Basic properties of the software solution}

Software may only be accessed by employees with adequate authorisations. The task of this application is to process and cross-reference the data regarding the functioning of the Integrated University which we can divide into two basic groups, as presented in Fig. 2:

- Import of payment reports issued by banks in XML format

- Import of students' profiles, data on contracts and listing of delivered services taken from university's information systems, also in XML format.

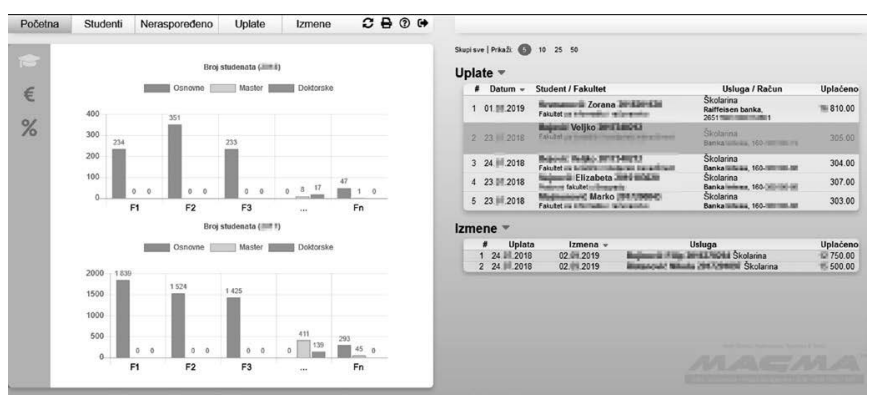

Fig. 3: Home page, general overview (demo data)

To ensure it is user friendly, application user interface has been simplified and standardised, containing graphic elements which are considered to standard in this industry, thus eliminating the need for user training, Fig. 3 and 4.

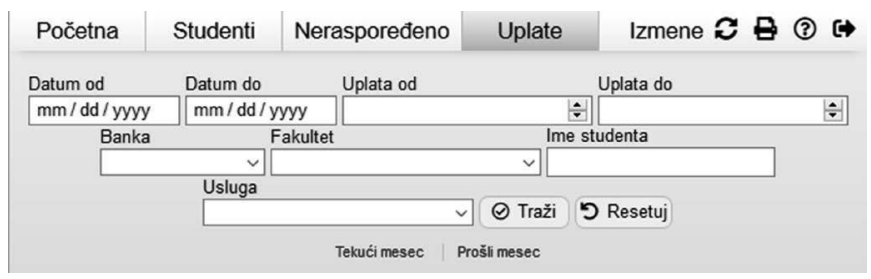

Fig. 4: Module Transactions, filter web form
The basic package contains the following modules:

- General overview. Graphic overview of the current cut-off of financial data per faculty and study program, with tabular overview of the latest imported transactions and changes made by the operator.

- Students. Module which enables the use of filters for University students per criterion assigned, whereby it is possible to create a desired subset of data for further analysis or to isolate an individual student.

- Undistributed. Transactions which were not identified automatically by the software, can be manually edited by the operator.

- Incoming payments. Review of processed transactions by using set criteria, with statistical grouping of data per faculty, payment purpose and bank accounts. Web form for data filtering is provided in Fig. 4.

- Changes. Listing of changes made to data by the operator.

The application has a modular architecture, where the business logic is separated from the presentation layer thus enabling expansion of the set of functionalities, if needed, by adding new modules.

\section{CONCLUSION}

Myriad of services provided by one company may often cause inadequate record-keeping and entry of data when it comes to execution. Problems which may arise concern mistaken matching of the amount paid and the payee's account. Even more often, the amounts paid are correctly matched to the client's account, but the services provided are mistakenly recorded. This may cause client dissatisfaction and bring about both the loss of the client and poorer business results. Inadequate matching of payments can give rise to negative publicity for the company or institution and thereby harm its business operations and market position. Particular problem may occur when off-the-shelf ERP solutions are procured which are not meant to recognize sensitivity of client's demands but are designed for the simplest transactions. This may also, and to a significant extent, cloud the management's judgement of the clients' requirements and guide them, on the basis of incomplete information, to reach inadequate decisions which will result in company's poorer performance. This issue is particularly conspicuous in companies which collect data from various information systems. For this reason, we believe that the presented software tool enables fast and simple insight into the nature of the transaction and service provided by the legal entity, per organisational unit. Adequate grouping of data and use of built-in tools for filtering can help identify possible irregularities and pinpoint the place of their origin. 
This method ensures that the management has a wide set of reports made up of accurate data at their fingertips at all times thus enabling it to reach high quality business decisions.

\section{ACKNOWLEDGEMENTS}

- Software presented in this paper was developed by prof. Milovan Stanišić, $\mathrm{PhD}$ and docent Miloš Dobrojević, $\mathrm{PhD}$.

- Magma Nano ${ }^{\text {tw }}$ platform (framework) on which the software is developed was designed by Miloš Dobrojević, $\mathrm{PhD}$.

\section{LITERATURE}

1. Barjaktarović, L., Jović, Z., \& Milojević, M. (2015). Poslovne finansije. Univerzitet Singidunum Beograd. ISBN: 978-86-7912-300-9.

2. Hall, J. (2011). Accountin Information Systems. New York: Wiley \& Sons.

3. Horngren, C., \& Harrison, W. (2012). Accounting. 9 ur. London: Prentice Hall.

4. Ivaniš, M., \& Nešić, S. (2011). Poslovne finansije. Beograd: Univerzitet Singidunum.

5. Jeremić, Z., Milojević, M., \& Terzić, I., (2015). Business performance of the largest exporters in Serbia during the period 2008-2014, Ekonomika preduzeća, Vol. LXIII, No. 5-6, pp. 293-305.

6. Lečić D., \& Kupusinac A. (2013). The Impact of ERP Systems on Business Decision-Making, TEM Journal, 2(4), 323-326.

7. Lutovac, M., \& Manojlov, D. (2012). The successful methodology for Enterprise Resource Planning Implementation, Journal of Modern Accounting and Auditing, 1838-1847.

8. Milojević, M., Terzić, I., Miletić, D., \& Stamenković, S. (2016). The Role of ERP Solutions in Managing Corporations From the Accounting Perspective. Sinteza 2016, 352-358.

9. Mittra, S. (1996). Decision Support System. New York: John Wiley \& Sons.

10. Marjanović, V., Ulrich, P., \& Milojević, M. (2014.). SAP System performance in cost center accounting: Evidence based on SQL trace reports. Sinteza, Belgrade 546-551.

11. Njeguš A. (2009). Poslovni informacioni sistemi, III izdanje. Beograd: Univerzitet Singidunum.

12. Petrović, Z., Knežević, G., \& Milojević, M. (2016). Računovodstveni Informacioni Sistemi. Univerzitet Singidunum. ISBN: 978-86-7912-625-2

13. Law on Higher Education, Ministry of Education and Science of the Republic of Serbia, Belgrade, 2017, available at: http://www.mpn.gov.rs/wp-content/uploads/2017/12/visoko-zakon.pdf, access from 03.09.2019.
14. Statute of the University of Singidunum, University of Singidunum, Belgrade, 2018, available at http://repository.singidunum.ac.rs/files/2018/03/Statut Univerziteta sa izmenama i dopunama.pdf, access from 03.09.2019.

15. Faculty Information System (FIS), Faculty of Eletrical Engineering, University of Belgrade, available at http://rc.etf.bg.ac.rs/projekti/fis?lang=sr, access from 02.09.2019.

16. FIMES Information Systems, Faculty of Electrical Engineering, University of Belgrade, available at http://rc.etf. bg.ac.rs/projekti/fimes?lang=sr, access from 02.09.2019.

17. Magma $\mathrm{Nano}^{\mathrm{mw}}$, Magma, available at http://en.magma. $\mathrm{rs} /$ software-solutions/magma-nano, access from 30.08.2019. 